\title{
Epidemiology of constipation in Europe and Oceania: a systematic review
}

\author{
George Peppas ${ }^{1}$, Vangelis G Alexiou ${ }^{1}$, Eleni Mourtzoukou ${ }^{1}$ and \\ Matthew E Falagas*1,2
}

\author{
Address: ${ }^{1}$ Alfa Institute of Biomedical Sciences (AIBS), Athens, Greece and ${ }^{2}$ Department of Medicine, Tufts University School of Medicine, Boston, \\ Massachusetts, USA \\ Email: George Peppas - peppasgr@yahoo.gr; Vangelis G Alexiou - v.alexiou@aibs.gr; Eleni Mourtzoukou - e.mourtzoukou@aibs.gr; \\ Matthew E Falagas* - m.falagas@aibs.gr \\ * Corresponding author
}

Published: 12 February 2008

BMC Gastroenterology 2008, 8:5 doi:10.1 186/147/-230X-8-5

This article is available from: http://www.biomedcentral.com/I47I-230X/8/5

(C) 2008 Peppas et al; licensee BioMed Central Ltd.

This is an Open Access article distributed under the terms of the Creative Commons Attribution License (http://creativecommons.org/licenses/by/2.0), which permits unrestricted use, distribution, and reproduction in any medium, provided the original work is properly cited.
Received: 8 August 2007

Accepted: 12 February 2008

\begin{abstract}
Background: We aimed to review the literature regarding the epidemiology of constipation in Europe and Oceania and the associated prevalence/risk factors.

Methods: Two reviewers performed PubMed searches and a hand search of references. A study was considered eligible for inclusion if it reported data about the prevalence of constipation in any population, free of other gastrointestinal disorders, in Europe and Oceania. Studies were evaluated for quality. Data regarding the setting, type of study, definition of constipation, study population, prevalence of constipation, factors associated with increased odds for constipation, and the female to male ratio, were collected.
\end{abstract}

Results: The 21 reviewed studies depict prevalence rates in 34 different population groups ranging widely from a low $0.7 \%$ to a high $81 \%$. In the general population of Europe the mean value of the reported constipation rates is $17,1 \%$ and the median value $16.6 \%$. Among the studies conducted in Oceania, the mean value of constipation prevalence was 15.3\%. Female gender, age and socioeconomic and educational class seem to have major effect on constipation prevalence. A number of various other risk factors are, less clearly, associated with constipation.

Conclusion: This systematic review depicts the high prevalence and related risk factors of a disorder that decreases the health-related quality of life and has major economic consequences.

\section{Background}

Gastrointestinal functional disorders and especially constipation are common morbidity factors in otherwise healthy persons as well as in patients with various predisposing diseases. In the general population, constipation is frequently reported, resulting in 2.5 millions of physician visits in the United States [1] and a total health care cost of $\$ 2752$ per patient treated [2]. The high prevalence rates, economic cost and adverse implications on the quality of life and health state $[3,4]$, make constipation a major public health issue.

Constipation is due to organic etiologies, such as mechanical obstruction, spinal cord injury [5], stroke, Parkinson's disease, hypothyroidism, diabetes [6] and local neurogenic disorders, e.g. Hirschsprung's disease [7] only for a 
minority of patients. The majority of cases are attributed to functional disorders without a structural underlying cause that could explain symptoms. Risk factors, such as dietary habits, physical inactivity [8], socioeconomic level, psychological parameters, medications [9], age [10], gender [11], etc have been implicated in the development of chronic functional constipation. However, the specific etiology of this gastrointestinal disorder has not been elucidated.

Only a small proportion of patients suffering from constipation seek medical advice; thus, the exact prevalence of the disorder is difficult to be estimated. A systematic review of studies on the epidemiology of constipation in North America [12] recorded various prevalence rates from a low $1.9 \%$ to a high $27.2 \%$. However, most of the included studies, report rates between $12 \%$ and $19 \%$. To our knowledge, no previous report of the current evidence has systematically reviewed the epidemiology of constipation in Europe or Oceania.

We sought to review the literature regarding the epidemiology of functional constipation in Europe and Oceania. Specifically, our purpose was to identify the prevalence of constipation in the general population and in special population groups, identify the risk factors associated with this functional disorder and compare the findings with those of the systematic review of the epidemiology of constipation in North America [12].

\section{Methods}

We performed a systematic review of the current evidence regarding the prevalence of constipation in Europe and Oceania. Two reviewers (EGM and VGA) having a medical degree searched the PubMed database (until December 2006) to identify relevant studies for inclusion. The key word used in the literature search was "constipation" combined with "incidence, prevalence, rate, proportion, epidemiology, or morbidity". Studies were limited to those written in English, French and referring to humans. The titles and abstracts of all studies identified were further reviewed to meet the entry criteria. Moreover, we performed a hand search of the references of the selected studies to identify potentially overlooked articles.

A study was considered eligible for inclusion if it reported data about the prevalence of constipation in any population, free of other gastrointestinal disorders, in Europe and Oceania. All studies involving cases of functional constipation, regardless the diagnostic criteria used were considered for inclusion. The diagnostic criteria range widely from self-report and parent-report for children, to consensus criteria like Rome II criteria [13]; at least 12 weeks, which need not be consecutive, in the preceding 12 months, of two or more of: $<3$ defecations per week
(DPW), hard or lumpy stools in $>1 / 4$ of defecations, straining in $>1 / 4$, digital manipulation of stools in $>1 / 4$, sensation of incomplete evacuation in $>1 / 4$, sensation of anorectal obstruction or blockage in $>1 / 4$.

Two of the authors (EM and VGA) retrieved and studied in detail the complete texts of the original articles that were relevant to the focus of our review. Agreement between the investigators was essential for data inclusion and few minor disagreements were resolved with the consent of the senior author. Data regarding the first author, year of publication, setting, type of study, definition of constipation, study population, prevalence of constipation, factors associated with increased odds for constipation, and the female to male ratio, were extracted. The above were tabulated in detail without taking into consideration the differences in methodology among the reviewed studies. We calculated the mean values for prevalence of constipation in Europe and Oceania by averaging the prevalence obtained in each study.

We used the critical appraisal guidelines for research articles determining prevalence, developed by Loney et al [14], to evaluate the quality of studies included in our systematic review. The scoring system consists of 8 questions on the validity of the study design (appropriate methods and frame, adequate size, suitable criteria, outcome measurements, and response rate), the interpretation (prevalence given with confidence intervals) and the applicability of the results (detailed description of subjects and settings), weighted equality with one point [15]. Thus the maximum quality score that a study could achieve was 8 .

\section{Results}

PubMed database returned a list of 2060 articles for the selected search string. From these, 2039 reports were excluded, after having reviewed their titles and abstracts, based on the criteria outlined in the Methods section. The full texts of the remaining 21 studies [16-36] were read and finally included in our systematic review. One more study [37] was identified following the hand search of references. However, Galvez et al evaluated a population already described by Garrigues et al study (included in this review). Reviewers disagreed on the inclusion of three studies $[25,26,33]$. However, they were included with the consent of the senior author.

In Tables 1, 2 and 3, we summarize the characteristics (author, year, type of study, depicted epidemiological data and quality score) of the reviewed studies regarding the prevalence of constipation in the general population of Europe, in special population groups of Europe and in all population groups of Oceania respectively. Overall the reviewed studies depict prevalence rates in 34 different 
$\stackrel{\infty}{\infty}$ Table I: Characteristics of studies regarding the epidemiology of constipation in Europe in the general population.

\begin{tabular}{|c|c|c|c|c|c|c|c|}
\hline $\begin{array}{l}\text { First author, year of } \\
\text { publication, setting }\end{array}$ & Type of study & Definition of constipation & $\begin{array}{l}\text { Study population (\% of } \\
\text { responders) }\end{array}$ & Prevalence per 100 & $\begin{array}{l}\text { Factors significantly associated } \\
\text { with increased odds for } \\
\text { constipation }\end{array}$ & $\begin{array}{l}\text { Quality } \\
\text { score }^{+}\end{array}$ & Comments \\
\hline $\begin{array}{l}\text { Siproudhis L } 2005 \text { France } \\
{[16]}\end{array}$ & $\begin{array}{l}\text { Mailed questionnaire } \\
\text { survey }\end{array}$ & $\begin{array}{l}\text { Emptying difficulties or unsatisfied } \\
\text { defecation during the preceding } 12 \text { - } \\
\text { month period }\end{array}$ & $\begin{array}{l}7196(72) \text { persons } \geq 15 \mathrm{yr}, \\
\text { representative of the general } \\
\text { population }\end{array}$ & 22.4 & History of vaginal delivery in women & 6 & F/M 2 \\
\hline $\begin{array}{l}\text { Garrigues V } 2004 \text { Spain } \\
\text { [17] }\end{array}$ & $\begin{array}{l}\text { Mailed questionnaire } \\
\text { study }\end{array}$ & $\begin{array}{l}\text { Self-reported, Rome I, and Rome II } \\
\text { criteria }\end{array}$ & $\begin{array}{l}349(71.4) \text { participants, } 18-65 \mathrm{yr} \text {, } \\
\text { representative of the general } \\
\text { population }\end{array}$ & $\begin{array}{l}29.5 \text { (self-reported) } 19.2 \\
\text { (Rome I criteria) I4 } \\
\text { (Rome II criteria) }\end{array}$ & Female gender & 7 & $\begin{array}{l}\text { F/M } 2.2 \text { Agreement } \\
\text { between self-reported and } \\
\text { Rome II criteria was } \\
\text { moderate }\end{array}$ \\
\hline $\begin{array}{l}\text { Walter S } 2002 \text { Sweden } \\
\text { [18] }\end{array}$ & $\begin{array}{l}\text { Mailed questionnaire } \\
\text { study }\end{array}$ & $\begin{array}{l}\text { Self-reported, as 'sometimes, often } \\
\text { or always' constipated }\end{array}$ & $\begin{array}{l}1610(80.5) \text { persons, } 31-76 \mathrm{yr} \text {, } \\
\text { randomly selected }\end{array}$ & 19.8 of women 8.3 of men & Female gender & 4 & F/M 2.4 \\
\hline $\begin{array}{l}\text { Haug TT } 2002 \text { Norway } \\
\text { [19] }\end{array}$ & $\begin{array}{l}\text { Mailed questionnaire } \\
\text { study }\end{array}$ & $\begin{array}{l}\text { Self-reported, as 'minor or major } \\
\text { complaints' during the last } 12 \\
\text { months }\end{array}$ & 62651 (66.5) persons, > $20 \mathrm{yr}$ & 20.2 & Anxiety, and less strongly depression & 4 & F/M 4 \\
\hline $\begin{array}{l}\text { Frexinos } 1998 \text { France } \\
\text { [20] }\end{array}$ & $\begin{array}{l}\text { Interview- } \\
\text { questionnaire survey }\end{array}$ & Self reported & $\begin{array}{l}6000(81) \text { participants }>15 \mathrm{yr} \text {, selected } \\
\text { by systematic random sampling }\end{array}$ & 35 & & 7 & \\
\hline $\begin{array}{l}\text { Gaburri } 1989 \text { Italy } \\
\text { Umbria [2I] }\end{array}$ & $\begin{array}{l}\text { Interview- } \\
\text { questionnaire survey, } \\
\text { performed by a } \\
\text { physician. }\end{array}$ & $\begin{array}{l}\leq 2 \text { DPW for }>9 \text { months in the last } \\
3 \text { years and/or straining at stool }> \\
75 \% \text { of the time }\end{array}$ & $\begin{array}{l}544(98) .104 \text { medical students, } 103 \\
\text { medical and paramedical employees } \\
\text { and } 326 \text { randomly selected home } \\
\text { interviewed persons. }\end{array}$ & 9.2 & $\begin{array}{l}\text { Female gender presented significantly } \\
\text { higher constipation rates. }\end{array}$ & 5 & \\
\hline $\begin{array}{l}\text { Bassotti G } 2004 \text { Italy } \\
\text { [22] }\end{array}$ & Prospective study & Rome II criteria & $\begin{array}{l}298(61) \text { persons recruited from the } \\
\text { general population and asked to } \\
\text { compile a daily diary on their bowel } \\
\text { habits and associated signs and } \\
\text { symptoms }\end{array}$ & $\begin{array}{l}5(<3 \text { DPW }) \\
11.7(\text { straining) } \\
\text { 10.7(incomplete } \\
\text { evacuation) }\end{array}$ & & 6 & \\
\hline
\end{tabular}

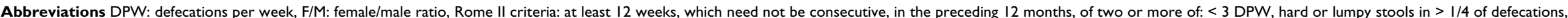

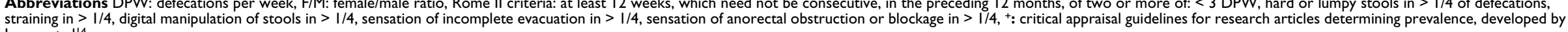


Table 2: Characteristics of studies regarding the epidemiology of constipation in Europe, in special populations groups.

\begin{tabular}{|c|c|c|c|c|c|c|c|}
\hline $\begin{array}{l}\text { First author, year of } \\
\text { publication, setting }\end{array}$ & Type of study & $\begin{array}{l}\text { Definition of } \\
\text { constipation }\end{array}$ & Study population (\% of responders) & Prevalence per 100 & $\begin{array}{l}\text { Factors significantly } \\
\text { associated with increased } \\
\text { odds for constipation }\end{array}$ & $\begin{array}{l}\text { Quality } \\
\text { score }^{+}\end{array}$ & Comments \\
\hline $\begin{array}{l}\text { Lopez Cara MA } 2006 \text { Spain } \\
\text { [23] }\end{array}$ & Mailed questionnaire survey & $\leq 3 \mathrm{DPW}$ & $\begin{array}{l}414 \text { (93) participants }>50 \mathrm{yr} \text {, selected by systematic } \\
\text { random sampling }\end{array}$ & 4.4 & $\begin{array}{l}\text { Consumption of olive oil, and } \\
\text { meat. }\end{array}$ & 4 & F/M 2 \\
\hline Kinnunen 1990 Finland [24] & $\begin{array}{l}\text { Interview-questionnaire survey } \\
\text { by public health nurse }\end{array}$ & $\begin{array}{l}\leq 3 \text { DPW, difficulties in } \\
\text { expelling stools because of } \\
\text { the hardness or anal canal } \\
\text { abnormalities }\end{array}$ & $\begin{array}{l}5 \text { groups of middle aged and elder population. } \\
\text { 1. Hospital: } 439 \\
\text { 2. Olds people's home: } 183 \\
\text { 3. Day hospital: } 78 \\
\text { 4. Home > } 74 \text { yrs: I38 } \\
\text { 5. Home } 4 \text { I- }-50 \text { yrs: } 74\end{array}$ & $\begin{array}{l}\text { Prevalence per } 100 \text { in the } 5 \\
\text { groups } \\
\text { Ist: females } 79 \text {, males } 81 \\
\text { 2nd: females } 57, \text { males } 64 \\
\text { 3rd: females } 30, \text { males } 25 \\
\text { 4th: females } 38 \text {, males } 37 \\
\text { 5th: females } 20 \text {, males } 3\end{array}$ & $\begin{array}{l}\text { Female gender. Fecal and urinary } \\
\text { incontinence. Age. Immobility. } \\
\text { Living in old people's homes and } \\
\text { geriatric hospital. Age over } 84 \\
\text { years. }\end{array}$ & 5 & \\
\hline Texerau 1989 France [26] & $\begin{array}{l}\text { Interview-questionnaire survey, } \\
\text { performed by a } \\
\text { gastroenterologist. }\end{array}$ & Self reported & $\begin{array}{l}667 \text { participants in } 4 \text { groups. } 82 \text { medical students, } 206 \\
\text { patients from local health center, } 210 \text { adults } \\
\text { interrogated in an occupational medicine office and } 69 \\
\text { persons from an olds people house. }\end{array}$ & 26 & & 3 & F/M 0.96 \\
\hline $\begin{array}{l}\text { Chin A Paw M } 2006 \text { The } \\
\text { Netherlands [27] }\end{array}$ & $\begin{array}{l}\text { RCT investigating the effects of } \\
\text { training on constipation, } \\
\text { questionnaire study }\end{array}$ & Defined below* & $\begin{array}{l}172(76.8) \text { participants living in long-term care } \\
\text { facilities, 64-94 yr }\end{array}$ & 22 & & 5 & \\
\hline $\begin{array}{l}\text { Ludvigsson JF } 2006 \text { Sweden } \\
\text { [28] }\end{array}$ & $\begin{array}{l}\text { Prospective cohort study, } \\
\text { questionnaire survey }\end{array}$ & Reported by parents & 834I (38.4) 2.5-yr-children from a birth cohort & 6.5 & $\begin{array}{l}\text { Low maternal education, female } \\
\text { sex, living in a large community, } \\
\text { lack of older siblings }\end{array}$ & 3 & \\
\hline Miele E 2004 Italy [30] & $\begin{array}{l}\text { Prospective study, data } \\
\text { obtained from } 13 \text { randomly } \\
\text { selected paediatricians }\end{array}$ & Rome criteria for children & 9660 children, 0-12 yr & 0.7 & & 5 & F/M 1.2 \\
\hline Soligo M 2006 Italy [3I] & Retrospective survey & $\begin{array}{l}\text { Decreased stool frequency, } \\
\text { difficult stool passage }\end{array}$ & $\begin{array}{l}786 \text { consecutive urogynecologic patients, average age } \\
60 \mathrm{yr}\end{array}$ & 31.7 & Posterior colpocele & 4 & \\
\hline
\end{tabular}

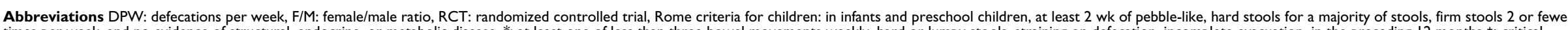

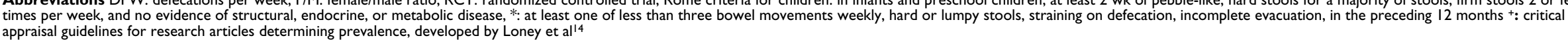

Table 3: Characteristics of studies regarding the epidemiology of constipation in Oceania.

\begin{tabular}{|c|c|c|c|c|c|c|c|}
\hline $\begin{array}{l}\text { First author, year of } \\
\text { publication, setting }\end{array}$ & Type of study & Definition of constipation & Study population (\% of responders) & Prevalence per 100 & $\begin{array}{l}\text { Factors significantly associated } \\
\text { with increased odds for } \\
\text { constipation }\end{array}$ & $\begin{array}{l}\text { Quality } \\
\text { score }^{+}\end{array}$ & Comments \\
\hline Howell SC 2006 Sydney [32] & Mailed questionnaire survey & Rome II criteria & $\begin{array}{l}1673(42.6) \text { persons, } 25-64 \mathrm{yr} \text {, randomly } \\
\text { selected from } 28 \text { districts }\end{array}$ & 30.7 & $\begin{array}{l}\text { Upper-middle educational social } \\
\text { class. Female gender. }\end{array}$ & 6 & F/M I.4 \\
\hline $\begin{array}{l}\text { Campbell } 1992 \text { New Zealand } \\
\text { [33] }\end{array}$ & $\begin{array}{l}\text { Interview-questionnaire } \\
\text { survey and a dietary } \\
\text { assessment }\end{array}$ & $\begin{array}{l}\leq 3 \text { DPW, strained at stools, taking } \\
\text { laxatives every } 2-3 \text { days }\end{array}$ & $\begin{array}{l}856(91) \text { participants }>70 \text { years registered with } \\
\text { the five general practitioners serving a rural } \\
\text { township of } 13500 \text { people }\end{array}$ & $\begin{array}{l}4.3 \text { had } \leq 3 \text { DPW } 20.3 \text { had } \\
\text { one of the three factors that } \\
\text { may indicate constipation }\end{array}$ & Female gender and age & 3 & F/M I.76 \\
\hline Bytzer P 200I Sydney [34] & Mailed questionnaire survey & $\begin{array}{l}\text { At least one of < } 3 \text { DPW, hard or } \\
\text { lumpy stools, anal blockage, during } \\
\text { preceding } 3 \text { months }\end{array}$ & $\begin{array}{l}8555 \text { (57), divided into } 5 \text { socioeconomic } \\
\text { classes, from Ist (highest) to } 5^{\text {th }} \text { (lowest) } \\
\text { quintiles }\end{array}$ & $\begin{array}{l}\text { Ist: } 6.3 \\
2^{\text {ndd: }} 8.7 \\
3^{\text {rdd: }}: 9.6 \\
4^{\text {th: }}: 10.3 \\
5^{\text {th: }}: 10.2\end{array}$ & Low socioeconomic class. & 6 & \\
\hline Chiarelli P 2000 Australia [35] & Questionnaire survey & $\begin{array}{l}\text { Sometimes or often experiencing } \\
\text { constipation symptoms during the } \\
\text { preceding } 12 \text { months }\end{array}$ & $\begin{array}{l}1476 \mid(4 I) \text { women } 18-23 \mathrm{yr} \\
14070(54) \text { women } 45-50 \mathrm{yr} \\
12893(37) \text { women } 70-75 \mathrm{yr}\end{array}$ & $\begin{array}{l}14.1(18-23 \mathrm{yr}) \\
26.6(45-50 \mathrm{yr}) \\
27.7(70-75 \mathrm{yr})\end{array}$ & $\begin{array}{l}\text { Haemorrhoids and 'other bowel } \\
\text { problems' in all three cohorts. } \\
\text { Parity in the young cohort. } \\
\text { Hysterectomy, prolapse repair, and } \\
\text { medications in the middle-aged and } \\
\text { older cohorts. }\end{array}$ & 3 & \\
\hline $\begin{array}{l}\text { Talley NJ } 2004 \text { New Zealand } \\
\text { [36] }\end{array}$ & Questionnaire survey & Defined below* & $\begin{array}{l}924 \text { persons } 26 \text { yr old, from a birth cohort ( } 94 \\
\text { of total original sample) }\end{array}$ & 19.9 & Female gender. & 5 & F/M I.3 \\
\hline
\end{tabular}

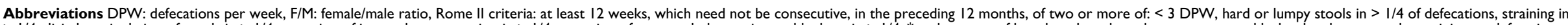

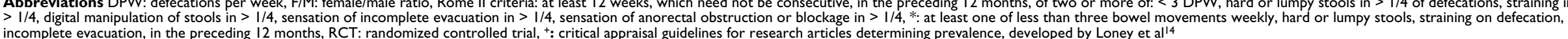


population groups ranging widely from a low $0.7 \%$ in a pediatric population in Italy [30] to a high $81 \%$ in a hospitalized, elderly, male population [24]. The mean value of the reported constipation rates is 22.3 and the median value 19.8. More than half of the reported constipation rates range from $8 \%$ to $26 \%$.

Seven studies have data on the prevalence of constipation in the general population in Europe (Table 1). The reported constipation rates range from a low $5 \%$ in a prospective study using the diagnostic criterion of $<3$ defecations per week (DPW) [22] to a high 35\% in an interview questionnaire survey of self-reported constipation [20]. The mean value of the reported constipation rates is 17.1 $\%$ and the median value $16.6 \%$. Nine studies depict constipation prevalence rates in special population groups in Europe: infants, children, elderly population, women and participants living in long-term care facilities (Table 2). Finally, 5 studies regarding the epidemiology of constipation in Oceania are tabulated in Table 3. The lowest prevalence was observed among an elderly population in New Zealand (4.3\%) [33]. Howel et al recorded the highest prevalence rate of constipation in the general population of Sydney Australia (30.7\%). Among the studies conducted in Oceania, the mean value of constipation prevalence is $15.3 \%$.

A secondary purpose of this review was to identify risk factors related with this functional constipation disorder. In particular, the predominance of females in the constipation prevalence is documented in most of the reviewed studies. In order to depict the exact magnitude of this association we present in Tables 1, 2 and 3 the female/ male ratio, in the studies where available. The mean and median value of the above ratio is calculated to 1.78 and 1.58 respectively. There are differences of the female/male ratio estimates by definition of constipation. However, the mean value remains above 1 for all case criteria, 1.7 for Rome I, 1.8 for Rome II, and 2.3 for self-report of constipation.

The effect of ageing on constipation prevalence has been recorded by 3 of the reviewed studies $[24,27,33]$. Socioeconomic and educational class influence on the constipation prevalence is also depicted in 3 studies $[28,32,34]$. Various other risk factors are associated with constipation by at least one research paper included in our systematic review of the current evidence; dietary habits like the consumption of olive oil and meat, life-style factors like living in a large community or old peoples home and immobility, frequency of breastfeeding, waist/hip ratio, anxiety and depression, co morbidities like hemorrhoids, other bowel disorders, previous hysterectomy and posterior colpocele and the use of medications like laxatives.

\section{Discussion}

The prevalence rates of constipation in Europe and Oceania as depicted by this review are consistent with the epidemiology of the disorder in North America [12]. Prevalence rates of constipation recorded in other developed countries are also within the same range; $14.3 \%$ in the general population in Hong-Kong [38], 16.5\% in the general population in Korea [39], 24.5\% in women in Taiwan [40], 26\% in a population of young women in Japan [41], 29.6\% in young children in Hong Kong [42], and $11.6 \%$ in an elderly Asian population [43]. The similarity of constipation rates recorded in the developed countries may partially be due to the common dietary habits of the studied populations. Constipation in individuals with previously normal bowel function is associated with specific dietary patterns; low fiber intake diet is involved with the pathogenesis of the disorder. Europe and Oceania are similar to North America in terms of health system and population's dietary habits, life style, physical activity and socioeconomic level.

Differing case definitions of constipation used, provide researchers with diverse prevalence rates. This is evident in the Garrigues et al study, where different diagnostic criteria were compared in the same individuals, resulting in significant differences in the depicted prevalence rates; $29.5 \%$ for self-report, $19.2 \%$ for Rome I criteria and $14 \%$ for Rome II criteria. We identified 3 studies using the Rome II criteria; the mean prevalence rate among these reports is $16.5 \%$. The relevant mean prevalence rates for Rome I criteria and self-report are $19.2 \%$ and $25.6 \%$ respectively. It should be mentioned that the Rome III consensus provides the most up to date definition and categorization of functional gastrointestinal disorders in children/adolescent [44] and neonate/toddler [45]. None of the reviewed studies implemented the Rome III criteria. Future studies on the epidemiology of constipation should rather be based on consensus diagnostic criteria.

Female gender is associated with elevated constipation prevalence rates $[17,18,21,25,32,33,36]$. In North America, females are 2.2 times more likely to report constipation than males [12]. This predominance of females has been attributed to hormonal factors, inflicting a higher risk of constipation during the luteal phase of the menstrual cycle, under the effect of progesterone, and damage to the pelvic floor muscles, which may occur in women during childbirth or gynecological surgery [35]. Posterior colpocele is an independent risk factor for constipation [31]; however, causal relationship between these disorders is difficult to be assumed.

In general, individuals of lower social, economic and educational level have a tendency towards higher constipation rates. Bytzer et al divided the sample of their 
questionnaire survey into five socioeconomic classes from $1^{\text {st }}$ (highest) to $5^{\text {th }}$ (lowest). They showed that the constipation prevalence rates among those five groups followed the pattern of their socioeconomic class, ranging from a low $6.3 \%$ for the $1^{\text {st }}$ class to a considerably higher $10.2 \%$ for the $5^{\text {th }}$ class. Of interest, according to another study [28], low maternal educational level is considered as a factor significantly associated with increased odds for constipation of the newborn.

Chiarelli et al questionnaire survey compares constipation prevalence among three age groups, 18-23 years, 45-50 years and 70-75 years and depicts considerable differences in prevalence rates; $14.1 \%, 26.6 \%$ and $27.7 \%$ respectively. A study focusing on infants followed up for 6 months, showed a prevalence rate of $17.6 \%$ [29]. This is surprisingly high when compared with the constipation prevalence in a pediatric population aged from $0-12$ years [30]; Miele et al used the Rome criteria in 9960 children and report a prevalence rate of $0.7 \%$.

Psychological factors and in particular anxiety and depression, are considered predisposing to constipation [19]. These psychological disorders, as well as obsessive compulsion and social dysfunction, have been implicated in the pathogenesis of constipation, are believed to slow down colonic transit, have greater impact on women, and are associated with less frequent use of coping strategies [38]. Behavioral treatment, specifically biofeedback, is alleged to ameliorate the course of the disorder and is frequently used as alternative therapy for persons with symptoms unresponsive to traditional medical treatment $[46,47]$.

Assessing quality in clinical trials is well described but much less attention has been given to similar strategies for observational epidemiological studies. We believe that the quality assessment tool used $[14,15]$ addresses efficiently the need for critical appraisal of prevalence studies. There were significant differences in the quality and methodology among the reviewed studies. The best score achieved was $7 / 8$ and the worst $3 / 8$ (Tables 1,2 and 3 ).

It should be acknowledge that when interpreting the findings of this systematic review one should take under consideration various limitations and shortcomings. First, the included studies use different definitions and diagnostic criteria of constipation, which could lead to inconsistencies regarding the prevalence estimates. No doubt, there is a discrepancy between self-reported constipation and the condition diagnosed based on the established Rome criteria. The rates are considerably higher when based on the definition of self-reported constipation [26]. This discrepancy highlighted by other investigators too [39], may be due to differences of personal perception regarding the problem, or could be involved with the validity of criteria. In addition, the use of questionnaires depends on the ability of the patient to recall symptoms, whereas prospective studies with the administration of diary cards are certainly more credible. Furthermore, the range of age groups studied is wide, and includes pediatric, as well as elderly study populations. Finally, it should be acknowledged that our search of the literature was limited to journals included in the PubMed database. However, the further hand search of references reduces possibly omitted studies. The language limit (articles published in English and French only) should be attributed to the available human resources. Despite this limitation, studies from 7 different European countries were included in our review (Spain, France, Italy, Netherlands, Norway, Sweden and Finland).

\section{Conclusion}

Because of the decrement in the health-related quality of life induced by constipation, and the economic consequences, physicians should be aware of the magnitude of the problem, and be able to give efficient instructions to patients for management, and particularly, prevention. We believe that our systematic review of current evidence on constipation provides a useful tool to physicians dealing with this high prevalence clinical problem, and a reference for future development of studies on the epidemiology and etiology of the disorder.

\section{Competing interests}

The author(s) declare that they have no competing interests.

\section{Authors' contributions}

GP conceived of the study, GP and MEF participated in its design and coordination. VGA, EM and MEF searched the literature and drafted the manuscript. All authors read and approved the final manuscript.

\section{References}

I. Sonnenberg A, Koch TR: Physician visits in the United States for constipation: 1958 to I986. Dig Dis Sci I989, 34(4):606-I I.

2. Rantis PC Jr, Vernava AM 3rd, Daniel GL, Longo WE: Chronic constipation - is the work-up worth the cost? Dis Colon Rectum 1997, 40(3):280-6.

3. Talley NJ: Definitions, epidemiology, and impact of chronic constipation. Rev Gastroenterol Disord 2004, 4(2):S3-SI0.

4. Dennison C, Prasad M, Lloyd A, Bhattacharyya SK, Dhawan R, Coyne $\mathrm{K}$ : The health-related quality of life and economic burden of constipation. Pharmacoeconomics 2005, 23:46I-76.

5. Krogh K, Christensen P, Laurberg S: Colorectal symptoms in patients with neurological diseases. Acta Neurol Scand 200I, I 03:335-43.

6. Vinik Al, Maser RE, Mitchell BD, Freeman R: Diabetic autonomic neuropathy. Diabetes Care. 2003, 26: I553-79.

7. Kessmann J: Hirschsprung's disease: diagnosis and management. Am Fam Physician 2006, 74:1319-22.

8. Peters HP, De Vries WR, Vanberge-Henegouwen GP, Akkermans LM: Potential benefits and hazards of physical activity and exercise on the gastrointestinal tract. Gut 200I, 48:435-9.

9. Talley NJ, Jones M, Nuyts G, Dubois D: Risk factors for chronic constipation based on a general practice sample. Am J Gastroenterol 2003, 98: I I07-II. 
10. Wald A: Constipation in elderly patients. Pathogenesis and management. Drugs Aging 1993, 3:220-31.

II. Chang L, Toner BB, Fukudo S, et al:: Gender, age, society, culture, and the patient's perspective in the functional gastrointestinal disorders. Gastroenterology 2006, I30:1435-46.

12. Higgins PD, Johanson JF: Epidemiology of constipation in North America: a systematic review. Am 」 Gastroenterol 2004, 99(4):750-9.

13. Drossman DA, Corazziari E, Talley NJ, Thompson WG, Whitehead WE: Rome II. The Functional Gastrointestinal Disorders. Diagnosis, Pathophysiology and Treatment: A Multinationa Consensus. 2nd edition. Edited by: McLean VA. Degnon Associates; 2000.

14. Loney PL, Chambers LW, Bennett KJ, Roberts JG, Stratford PW: Critical appraisal of the health research literature: prevalence or incidence of a health problem. Chronic Dis Canada 2000, 19: 170-77.

15. Loney P, Stratford P: Prevalence of low back pain in adults: a methodological review of the literature. Physical Therapy 1999 , 79(4):384-96

16. Siproudhis L, Pigot F, Godeberge P, Damon H, Soudan D, Bigard MA: Defecation disorders: a French population survey. Dis Colon Rectum 2006, 49:219-27.

17. Garrigues V, Galvez C, Ortiz V, Ponce M, Nos P, Ponce J: Prevalence of constipation: agreement among several criteria and evaluation of the diagnostic accuracy of qualifying symptoms and self-reported definition in a population-based survey in Spain. Am J Epidemiol 2004, 159:520-6.

18. Walter S, Hallbook O, Gotthard R, Bergmark M, Sjodahl R: A population-based study on bowel habits in a Swedish community: prevalence of faecal incontinence and constipation. Scand Gastroenterol 2002, 37:91।-6.

19. Haug TT, Mykletun A, Dahl AA: Are anxiety and depression related to gastrointestinal symptoms in the general population? Scand J Gastroenterol 2002, 37:294-8.

20. Frexinos J, Denis P, Allemand H, Allouche S, Los F, Bonnelye G Descriptive study of digestive functional symptoms in the French general population. Gastroenterol Clin Biol 1998, 22(10):785-9I.

21. Gaburri M, Bassotti G, Bacci G, et al.: Functional gut disorders and health care seeking behavior in an Italian non-patient population. Recenti Prog Med 1989, 80(5):24|-4.

22. Bassotti G, Bellini M, Pucciani F, et al:: An extended assessment of bowel habits in a general population. World J Gastroenterol 2004, 10:7|3-6.

23. Lopez Cara MA, Tarraga Lopez PJ, Cerdan Oliver M, et al.: Constipation in the population over $\mathbf{5 0}$ years of age in Albacete province. Rev Esp Enferm Dig 2006, 98:449-59.

24. Kinnunen O: Study of constipation in a geriatric hospital, day hospital, old people's home and at home. Aging | $199 \mid$, 3(2): $161-70$

25. Bommelaer G, Rouch M, Dapoigny M, et al.: Epidemiology of intestinal functional disorders in an apparently healthy population. Gastroenterol Clin Biol 1986, I0(I):7-I2.

26. Texereau $P$, Liversain JM: [Epidemiology of intestinal functiona disorders]. Presse Med 1989, 18(26): $1281-4$

27. Chin A Paw MJ, van Poppel MN, van Mechelen W: Effects of resistance and functional-skills training on habitual activity and constipation among older adults living in long-term care facilities: a randomized controlled trial. BMC Geriatr 2006, 6:9.

28. Ludvigsson JF, Abis Study Group: Epidemiological study of constipation and other gastrointestinal symptoms in 8000 children. Acta Paediatr 2006, 95:573-80.

29. lacono G, Merolla R, D'Amico D, et al.: Gastrointestinal symptoms in infancy: a population-based prospective study. Dig Liver Dis 2005, 37:432-8.

30. Miele E, Simeone D, Marino A, et al: Functional gastrointestinal disorders in children: an Italian prospective survey. Pediatrics 2004, I I 4:73-8.

31. Soligo M, Salvatore S, Emmanuel AV, et al: Patterns of constipation in urogynecology: clinical importance and pathophysiologic insights. Am J Obstet Gynecol 2006, 195:50-5.

32. Howell SC, Quine S, Talley NJ: Low social class is linked to upper gastrointestinal symptoms in an Australian sample of urban adults. Scand J Gastroenterol 2006, 41:657-66.
33. Campbell AJ, Busby WJ, Horwath CC: Factors associated with constipation in a community based sample of people aged 70 years and over. J Epidemiol Community Health 1993, 47(I):23-6.

34. Bytzer P, Howell S, Leemon M, Young LJ, Jones MP, Talley NJ: Low socioeconomic class is a risk factor for upper and lower gastrointestinal symptoms: a population based study in 15000 Australian adults. Gut 200I, 49:66-72.

35. Chiarelli P, Brown W, McElduff P: Constipation in Australian women: prevalence and associated factors. Int Urogynecol J Pelvic Floor Dysfunct 2000, I I:71-8.

36. Talley NJ, Howell S, Poulton R: Obesity and chronic gastrointestinal tract symptoms in young adults: a birth cohort study. Am J Gastroenterol 2004, 99: 1807-14.

37. Galvez C, Garrigues V, Ortiz V, Ponce M, Nos P, Ponce J: Healthcare seeking for constipation: a population-based survey in the Mediterranean area of Spain. Aliment Pharmacol Ther 2006, 24(2):42I-8.

38. Cheng C, Chan AO, Hui WM, Lam SK: Coping strategies, illness perception, anxiety and depression of patients with idiopathic constipation: a population-based study. Aliment Pharmacol Ther 2003, 18:319-26.

39. Jun DW, Park HY, Lee OY, et al: A population-based study on bowel habits in a Korean community: prevalence of functional constipation and self-reported constipation. Dig Dis Sci 2006, 5 I: | $47 \mid-7$.

40. Chen GD, Hu SW, Chen YC, Lin TL, Lin LY: Prevalence and correlations of anal incontinence and constipation in Taiwanese women. Neurourol Urodyn 2003, 22:664-9.

4I. Murakami K, Okubo H, Sasaki S: Dietary intake in relation to selfreported constipation among Japanese women aged 18-20 years. Eur J Clin Nutr 2006, 60:650-7.

42. Ip KS, Lee WT, Chan JS, Young BW: A community-based study of the prevalence of constipation in young children and the role of dietary fibre. Hong Kong Med I 2005, I I:43I-6.

43. Wong ML, Wee S, Pin CH, Gan GL, Ye HC: Sociodemographic and lifestyle factors associated with constipation in an elderly Asian community. Am / Gastroenterol 1999, 94:|283-9|.

44. Rasquin A, Di Lorenzo C, Forbes D, et al:: Childhood functional gastrointestinal disorders: child/adolescent. Gastroenterology 2006, 130:1527-37.

45. Hyman PE, Milla PJ, Benninga MA, et al.: Childhood gastrointestinal disorders: neonate/toddler. Gastroenterology 2006, 130:1519-26.

46. Mason HJ, Serrano-lkkos E, Kamm MA: Psychological state and quality of life in patients having behavioral treatment (biofeedback) for intractable constipation. Am J Gastroenterol 2002, 97:3154-9.

47. Chiotakakou-Faliakou E, Kamm MA, Roy AJ, Storrie JB, Turner IC Biofeedback provides long-term benefit for patients with intractable, slow and normal transit constipation. Gut 1998, 42:5|7-2|.

\section{Pre-publication history}

The pre-publication history for this paper can be accessed here:

http://www.biomedcentral.com/1471-230X/8/5/prepub 